\title{
Effects of diameter-limit by-laws on forestry practices, economics, and regional wood supply for private woodlands in southwestern Ontario
}

\author{
Terry D. Schwan ${ }^{1}$ and Ken A. Elliott ${ }^{2}$
}

\begin{abstract}
The agriculturally dominated Counties of Huron and Perth in southwestern Ontario regulate forest harvesting on private land through diameter-limit-based tree conservation by-laws. The rates of harvesting, along with the volume and value of timber sales and the type and quantity of tree marking were examined for the years 1997 to 1999. Although these harvests may form an important part of periodic farm income, at only $13 \%$ forest cover, these landscapes maybe further degraded by unsustainable forest harvesting practices. Based on the three study years, the mean annual area of forest harvested was found to be $4.4 \%$ of the total private forest landbase. The mean volume harvested from upland and lowland deciduous forest was 4666 and $6148 \mathrm{fbm} / \mathrm{ha}$, respectively. Over-harvesting under a diameter-limit or hybrid method occurred in $8 \%$ of woodlot area with removal rates in excess of $10000 \mathrm{fbm} / \mathrm{ha}$. The most severe over-harvesting disproportionately targeted lowland woodlots, possibly compromising the ecological health of these often sensitive areas. Sugar maple, red/silver maple and ash were most commonly harvested at $33 \%, 31 \%$ and $21 \%$ of total species volume, respectively. On average, for standing timber, landowners received $\$ 680 / \mathrm{Mfbm}$ in the upland hardwood forests and $\$ 281 / \mathrm{Mfbm}$ in the lowland hardwood forests. On an area basis, mean price paid was $\$ 3680 /$ ha and $\$ 1956 /$ ha respectively on upland and lowland forests. Only $8 \%$ of the private land was harvested using single-tree selection or stand improvement (92\% harvest was diameter-limit or a hybrid of same). Using a simple model, we found that woodlot owners comprising at least $74 \%$ of private woodland area would need to participate in forest harvesting in order to maintain the 1997 to 1999 partial harvest area rate of $2349 \mathrm{ha} / \mathrm{yr}$. This rate may not be sustainable, given poor forest conditions in some areas, past management practices and a reduction in landowners interested in forest harvesting. Improvements are needed to bring the level of good forestry practice up by $62 \%$ to meet the rates that were being performed under pre-1994, free, provincial government private land forestry programs.
\end{abstract}

Key words: private land forestry, forest harvesting, forest conservation by-laws, sustainable forest management, diameterlimit harvest, private woodlots

\section{RÉSUMÉ}

Dans les comtés de Huron et de Perth situés dans le sud-ouest de l'Ontario où l'agriculture est prépondérante, la coupe de bois en forêt privée est régie par des directives de conservation en fonction du diamètre minimal de larbre. Le taux de récolte, en plus du volume et de la valeur des ventes de bois, ainsi que le type et limportance du marquage des arbres ont été étudiés pour la période de 1997 à 1999. Même si ces coupes peuvent constituer une partie importante des revenus périodiques d'une ferme, ces écosystèmes qui comptent pour seulement $13 \%$ du couvert forestier, pourraient connaître une dégradation plus poussée lorsquexposés à des pratiques non durables d’exploitation forestière. En fonction de ces trois années sous étude, la superficie annuelle moyenne de forêt exploitée équivalait à $4,4 \%$ de la superficie totale des forêts privées. Le volume moyen récolté des forêts feuillues sèches et des forêts feuillues humides était respectivement de 4666 et de $6148 \mathrm{pmp} / \mathrm{h}$. La surexploitation en fonction du diamètre minimal ou d'une méthode hybride est survenue dans $8 \%$ du territoire forestier privé entraînant des taux d'extraction supérieurs à $10000 \mathrm{pmp} / \mathrm{ha}$. Les plus importantes surexploitations ont été effectuées de façon totalement disproportionnée dans les forêts humides, compromettant probablement la santé écologique de ces zones souvent fragiles. Lérable à sucre, l'érable rouge/argenté et le frêne constituaient les essences les plus souvent récoltées, comptant respectivement en volume par espèce pour $33 \%, 31 \%$ et $21 \%$. Les propriétaires de boisés reçoivent en moyenne pour du bois sur pied 680\$/mpmp tiré des forêts feuillues sèches et $281 \$ / \mathrm{mpmp}$ pour le bois des forêts feuillues humides. En fonction de la superficie, le prix moyen versé atteignait $3680 \$ /$ ha et $1956 \$ / h a$ pour respectivement les forêts sèches et pour les forêts humides. Seulement $8 \%$ des forêts privées ont été exploitées selon un jardinage par arbre ou un système d'amélioration du peuplement ( $92 \%$ de la récolte étant réalisé par coupe au diamètre minimal ou un hybride de cette méthode). Au moyen d'un modèle simple, nous avons constaté que les propriétaires de boisés privés totalisant au moins $74 \%$ de la superficie des forêts privées auraient dû entreprendre des travaux d'exploitation de façon à pouvoir maintenir le taux de coupe partielle en 1997 et 1999 de 2349 ha/a. Ce taux nest probablement pas durable, étant donné le mauvais état des forêts dans certaines régions, les pratiques d’aménagement du passé et la baisse du nombre de propriétaires intéressés à exploiter leurs boisés. Des améliorations sont requises pour pouvoir amener le niveau de saines pratiques forestières à près de $62 \%$ correspondant à ce qui a été atteint avant 1994 grâce à des programmes gratuits d’aide en forêt privée de la part du gouvernement provincial.

Mots clés : foresterie sur terrain privé, exploitation forestière, directives de conservation des forêts, aménagement forestier durable, coupe au diamètre minimal, boisés privés

\footnotetext{
${ }^{1}$ Ontario Ministry of Natural Resources, Guelph District. One Stone Road West, Guelph, Ontario N1G 4Y2. Corresponding author. E-mail: terry.schwan@ontario.ca

${ }^{2}$ Ontario Ministry of Natural Resources, Southern Science and Information Section, 659 Exeter Road, London, Ontario, N6E 1L3. E-mail: ken.elliott@ontario.ca
} 


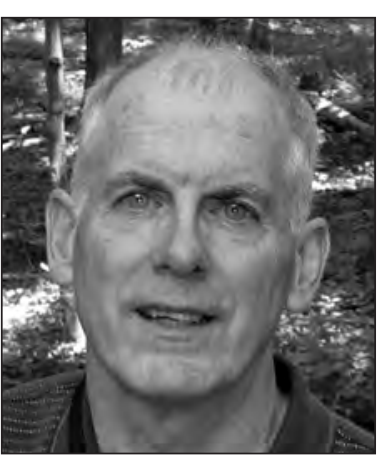

Terry D. Schwan

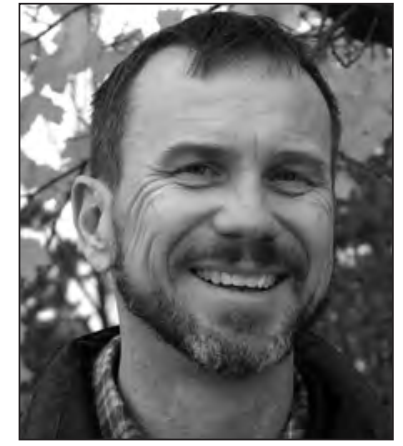

Ken A. Elliott

\section{Introduction}

Since European settlement, most forests in southwestern Ontario have been cleared for agriculture or utilized for forest products. Agriculture is the economic driver in the study area where forest cover has been reduced to $13 \%$ of the landbase (Voros 2008). Most landowners have retained some wooded area on their properties, which contribute to farm income through the production of lumber, maple products, fuelwood, and pasture. Forest harvesting continues to be an important modifier of forest ecosystems throughout southwestern Ontario. The previously common practice of clearcut logging has virtually disappeared since the 1950s. Today, commercial partial harvests occur on a 10- to 60-year cycle, depending on the intensity of past cutting and landowner objectives. These activities have provided the disturbance regime that is currently directing succession, stand structure, species composition and forest health.

Until the enactment of enabling legislation known as the Trees and Forest Conservation Act of 1946 (pertinent provisions evolved into the Municipal Act), there was no regulation of forest harvest on private land. The Act gave interested Counties the ability to pass by-laws regulating the harvest of trees. Since this time the most common regulation tool had been to set minimum diameters by species groups, below which all trees must be retained. Diameter-limit harvests usually result in the removal of all the commercially valuable trees. Depending on the pre-harvest stand structure, the residual forest can range from a virtual clearcut, to a stand "highgraded" with residual stems comprised of small or of poorquality trees often left in unthinned clumps. Under such a harvesting regime, there is no regard for species composition, regeneration, genetics, forest health or correct spacing for optimum growth (Kenefic and Nyland 2005). For these reasons diameter-limit harvesting is considered poor forestry practice.

There is little information on harvest rates and whether they are sustainable on private land in this region. The current forest cover in Huron County is 16\% and 9\% in Perth County, (Voros 2008). Concerned about these low levels of cover, the Counties have used the diameter-limit regulation method in their tree conservation by-laws to prevent clearcutting or land clearing on private woodlots. The by-laws in these municipalities also require landowners to submit a Notice of Intent (NOI) in advance of any harvest. These documents are intended to identify the owner, the location, the timing of harvest, the tree species being removed and the contractor who will conduct the work. This allows for follow-up inspec- tions to determine compliance with the by-law. Harvest rates for these Counties and on private land throughout Ontario have been poorly documented, despite the availability of data in tree by-law submissions, such as NOIs.

The forest industry in this region consists of a number of small independent sawmills and loggers. Currently there is no system for region-wide forest planning and harvest regulation. Agencies have limited knowledge of wood supply and the forest inventory is outdated. ${ }^{3}$ It is unclear whether the forests are able to support the current rate of forest harvesting or the length of time that rate can be sustained.

Farmers and woodlot owners often rely on periodic income from their woodlot. Depending on the size of the woodlot and the quality, species and size of the trees, periodic forest income could amount to tens of thousands of dollars. There is poor knowledge among landowners, the forest industry and the citizens of Ontario of the economic value and importance of forests. No recent studies in Ontario have shown the overall value of the private land timber harvest to a region or the province.

Since the mid-1990s, when the Province reduced its role in providing assistance to private woodland owners, the forestry consultancy has expanded and matured. Forestry consultants usually hold qualifications such as membership in the Ontario Professional Foresters Association or Provincial certification as tree markers. Many landowners utilized the consultants' services to have a harvest conducted in their woodlot, while most others deal directly with loggers and log buyers.

For many years, foresters, municipal leaders, ecologists and forest industry experts have wondered about the impacts of current harvesting practices and their intensity on the forest ecosystems of southern Ontario. This unique study has chosen a typical agricultural landscape in the area and has combined information and data from the municipalities' Notices of Intent, the logging contractors (interviews and surveys) and forestry consultants (tree marking records).

The objectives of this study are to:

- quantify the area and volume harvest rates in Huron and Perth Counties between 1997 and 1999,

- evaluate wood supply sustainability given management approaches and harvest rates, and

- quantify the economic value of wood harvesting to forest landowners during this time frame.

\section{Methods \\ Study area}

This study was conducted in the Counties of Huron and Perth in southwestern Ontario, (Fig. 1) which lie within the Great Lakes - St. Lawrence Forest Region (Rowe 1972) or Site Region 6E (Hills 1959). The southern portions of both counties are in the transition zone between Site Region $6 \mathrm{E}$ and 7E, with a small portion of the southwest corner of Huron County within the Deciduous Forest Region (Site Region 7E; Hills 1959). Sugar maple (Acer saccharum Marsh.), beech (Fagus grandifolia Ehrh.), and associates white ash (Fraxinus americana L.), black cherry (Prunus serotina Ehrh.) and basswood (Tilia americana L.) are the main tree species found on

${ }^{3}$ The last forest inventory in southern Ontario private land was conducted in 1978. 


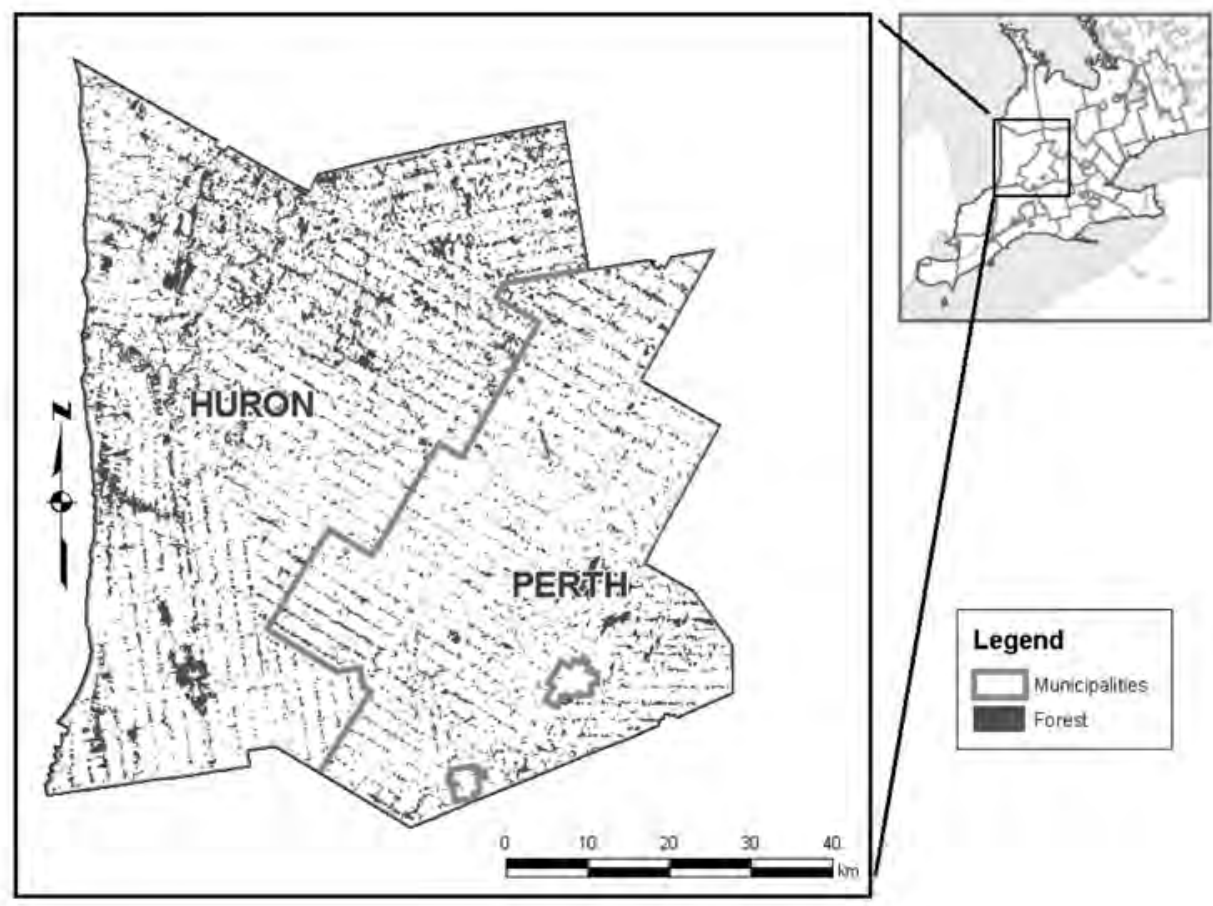

Fig. 1. Location of the study area in southwestern Ontario.

well-drained sites. Silver and red maple and their hybrids (Acer saccharinum L., A. rubrum L. and A. $\times$ fremanii A.E. Murray), red, green and black ash (Fraxinus pensylvanica Marsh., F. pensylvanica var. subintegerrima [Vahl] Fern., F. nigra Marsh), and white cedar (Thuja occidentalis L.) are common in the poorly drained depressions and river valleys. Other tree species commonly found are eastern hemlock (Tsuga canadensis [L.] Carrière), eastern white pine (Pinus strobus L.), bitternut hickory (Carya cordiformis [Wangenh.]), yellow and white birch (Betula alleghaniensis Britt., B. papyrifera Marsh.), poplar species (Populus spp.), red and bur oak (Quercus rubra L., Q. macrocarpa Michx.), ironwood (Ostrya virginiana [Mill.] K. Koch) and elm species (Ulmus spp.). In the south, black walnut (Juglans nigra L.) and white oak (Quercus alba L.) may also be found (Rowe 1972).

Most of Perth County is situated on the Stratford Till Plain where soils have good natural fertility and there are few obstacles to cultivation once drainage is applied (Chapman and Putnam 1984). About one-third of the area of Huron County is on till plain. The Horseshoe Moraines cut through the County in a north-south direction and have more rugged, agriculturally challenging topography that has resulted in higher forest cover retention of 19\%. The Huron Slope landform lying west of the Horseshoe Moraines, although a less severe topography than the moraine (13\% forest cover), also has retained a higher forest cover than the $9 \%$ found on the till plain (Schwan, SOLRIS analysis, unpublished, 2010).

Although the initial study and analysis was separated by County we have combined the two to simplify reporting. Where important differences between counties were found, we have advised the reader.

\section{Data collected}

Data were collected for the years 1997 to 1999 using three main sources: 1) Notices of Intent (NOIs) filed with the municipalities, 2) logging contractor records based on surveys and interviews, and 3) a survey of forestry consultant records.

\section{Notices of Intent}

Notice of Intent (NOI) records for the counties of Huron and Perth were obtained from municipal offices for the years 1997 through 1999. For each NOI, the property owner's name, township, location (lot and concession), size of woodlot, expected starting date (month and year only, if not available, the month and year of the filed NOI record was used), species of trees to be cut and the name of the contractor were recorded. Duplicate NOI records were removed. NOI records from one large landowner were consolidated from 12 to four, and some were not considered because they were for the harvest of fencerows. For notices in Perth County, the size of "area requesting permission to cut" was recorded. This was used in lieu of size of the woodlot in all subsequent analysis. Perth County NOI records often contained the tree by-law officer's report with type of the harvest and the name of the tree marker noted.

Forest type was determined from a combination of the NOI species information, the Forest Resource Inventory of 1978 and from subsequent data collected from consultants and contractors. The forest type of the NOI was categorized as 1) upland hardwood, 2) lowland hardwood, 3) plantation, or 4) not determined. A small number of NOI woodlots were a mix of upland and lowland areas or included intolerant forest stands with aspen/birch in the harvest or included some 
harvest of cedar and hemlock. They were allocated using the combined resources listed above and were all categorized into one of the four groups listed.

\section{Contractor survey}

A list of logging contractors operating in the study area was generated, as well as the number of NOIs filed by each contractor. Contractors were contacted and additional information on the woodlots for which they had filed a NOI, was requested. This included month and year of harvest, total number of trees or logs harvested, volume harvested by species, marker's name and type of marking, price paid to landowner and type of purchase. Hard maple, soft maple, ash (white, green, red and black combined), black cherry, American beech, oak (white, red and bur combined), and white pine were separated as species. The volume of all other species was grouped. The more active loggers and sawmills (with more than $\sim 20$ NOI) were visited and information was collected in person. A questionnaire was mailed to the other loggers and sawmills and telephone contact was made. The forms were filled out at their discretion and in many cases not all information requested was supplied.

\section{Consultant survey}

Tree marking records were obtained from the four independent forest consultants operating within the study area. Each marking record was matched, where possible, to the corresponding NOI based on the property owner, location and date of harvest. The consultant, date of marking, area marked, and number of trees and estimated volume marked by species, were recorded for each record with a corresponding NOI. In subsequent analysis, the area marked was used in lieu of the size of woodlot or the size of area requesting permission to cut (from the NOI) because it was a more accurate measure of harvest area. Marking was categorized as single-tree selection, improvement cutting ${ }^{4}$, legal size as defined in the by-law (diameter-limit), and hybrid. A few consultants described a hybrid marking approach. We have defined hybrid marking as a diameter-limit harvest that meets the tree by-law requirements, with the retention of a few good quality trees above the diameter limit and the removal of most poorquality large trees. In some cases, if the owner requested to harvest fuelwood for personal purposes, small poor-quality trees or trees from a smaller size class requiring thinning were removed in the hybrid marking. Plantation marking was a small proportion of the overall marking and is not reported.

\section{Harvest modeling}

By reviewing the results of our study we were able to develop a simple, area-based, harvest model using a Microsoft ${ }^{\oplus}$ Office Excel 2003 spreadsheet. It is designed to allow for projections of annual area harvested and available for harvest based on a set of assumptions, derived from our study. As well, the model is used to test for the sustainability of different available harvest areas or annual harvest rates over a long-term modeling horizon (usually 100 years). The model inputs include:

${ }^{4}$ Improvement cuttings are made in stands greater than $10 \mathrm{~cm}$ DBH for the purpose of improving composition and quality by removing trees of undesirable species, form or condition from the main canopy (Smith 1986). Normally, the product derived from this harvest is fuelwood.
Model Input \#1: Private Deciduous Forest Landbase Huron and Perth Counties $=53000$ ha (See Table 2)

Model Input \#2: Annual Harvest Rate - based on three-year study $(1997-1999)=2349 \mathrm{ha} / \mathrm{yr}($ See Table $2 ; 7047 \mathrm{ha} / 3$ years $=2349 \mathrm{ha} / \mathrm{yr}$ )

There are four model assumptions:

Assumption \# 1: Area Available for Harvest - \% of landbase (landowners) available for harvest. This could be changed to test for sustainability; a $66 \%$ scenario is tested based on local evidence regarding level of interest in harvesting (see Results, Model of harvest rate)

Assumption \#2: 8\% of harvest area marked for single-tree selection or stand improvement (see Results, Forest management practices) and will have a 10-year cutting cycle

Assumption \#3: 8\% of harvest area severely over-cut by volume and will have a 40-year cutting cycle (see Results, Estimating sustainability of wood volume)

Assumption \#4: 84\% or the remaining area has various cutting intensities and uncertain growth rates but can be conservatively assigned a 15-year cutting cycle

The spreadsheet has:

i) a column of Harvest Years from 0 to 100,

ii) an Available Harvest Area column (Assumption \#1 $\times$ Model Input \#1) for year 0; each following year must remove the area cut the previous year and add the areas that return at the appropriate cutting cycle length based on Assumptions \#2, 3 and 4,

iii) an Annual Cut column, area set as Model Input \#2 or the Available Harvest Area if it is less,

iv) three columns: 10-year, 15-year, and 40-year Cutting Cycle divides the Annual Cut area up among Assumptions \#2, 3 and 4.

By running the model with various inputs to Assumption $\# 1$, we can test to see what the threshold \% of the landbase is needed to ensure the 1997 to 1999 annual harvest rate can be sustained over the 100 -year projection.

\section{Analysis}

All data were entered using Microsoft ${ }^{\oplus}$ Office Access 2003 into three databases according to NOI, contractor data and consultant data. Data queries were used to cross-reference data and to develop relationships. Summaries and statistical analysis were conducted using Microsoft ${ }^{\circledR}$ Office Excel 2003 Statistical Analysis ToolPak. Means were developed for all summary data. Standard error of the mean was used to illustrate annual value paid to the landowner for timber. The correlation statistic was used to compare volume harvested with price of timber. A two-sample Student's t-test with unequal variances (0.01 significance level) was used to differentiate mean volumes in upland and lowland hardwood harvests.

\section{Results}

\section{Forest harvest and sustainability}

Area summary

Table 1 summarizes the NOI information for Huron and Perth Counties. It is assumed that we collected the basic NOI information for $99 \%$ of the commercial harvest operations. Tree by-law officers confirmed that a NOI was filed for almost all properties where commercial logging was done. A $1 \%$ lack of compliance is a fair estimate (about 11 NOIs) based on our data. We found a few instances of a consultant marking file 
Table 1. Summary of Notice of Intent (NOI) and total harvest area (ha) by municipality from 1997 to 1999 . Total harvest includes plantation and "not determined".

\begin{tabular}{lcccc}
\hline & & & & Grand \\
& $\mathbf{1 9 9 7}$ & $\mathbf{1 9 9 8}$ & $\mathbf{1 9 9 9}$ & Total \\
\hline NOI (\#) & & & & \\
Huron County & 238 & 269 & 302 & 809 \\
Perth County & 66 & 131 & 102 & 299 \\
Total NOI & $\mathbf{3 0 4}$ & $\mathbf{4 0 0}$ & $\mathbf{4 0 4}$ & $\mathbf{1 1 0 8}$ \\
& & & & \\
Harvest area (ha) & & & & \\
Huron County & 1663 & 2080 & 2241 & 5984 \\
Perth County & 401 & 741 & 588 & 1730 \\
Total harvest area & $\mathbf{2 0 6 4}$ & $\mathbf{2 8 2 0}$ & $\mathbf{2 8 2 9}$ & $\mathbf{7 7 1 4}$ \\
\hline
\end{tabular}

Table 2. Forest cover data in the Huron and Perth Counties. See Appendix I for explanation of calculations. (Spectranalysis, Inc. 1999]

\begin{tabular}{lcc}
\hline & Hectares & Percent \\
\hline Huron County & 341840 & - \\
Total area & 51900 & - \\
Total forest area & - & 15.2 \\
Percent of forest land & 39300 & - \\
Deciduous forest area & 1300 & - \\
Public-owned deciduous forested area & 38000 & - \\
Privately-owned deciduous forest area & $5376^{\mathrm{a}}$ & 14.1 \\
Private deciduous forest harvest area & & \\
$\quad$ (1997-1999) & - & 4.7 \\
Percent mean annual harvest for private & & \\
$\quad$ deciduous forests. & & \\
& 222969 & - \\
Perth County & 19501 & - \\
Total area & - & 8.7 \\
Total forest area & 15500 & - \\
Percent of forest land & 500 & - \\
Deciduous forest area & 15000 & - \\
Public-owned deciduous forested area & $1671^{\mathrm{a}}$ & 11.1 \\
Privately-owned deciduous forest area & & \\
Private deciduous forest harvest area & & \\
$\quad$ (1997-1999) & - & 3.7 \\
Percent mean annual harvest for private & & \\
deciduous forests. & & \\
\hline
\end{tabular}

a area values differ from Table 1 due to exclusion of plantation and "not determined". that did not match a NOI or a NOI filed for one landowner and an abutting neighbour took advantage of the presence of the contractor and harvesting occurred on the second property without the filing of a second NOI.

For purposes of analysis 1108 NOIs were used covering 7714 ha. The 809 NOIs filed in Huron County and 299 NOIs in Perth County accounted for a harvest area of 5984 ha and 1730 ha, respectively. The NOI and harvest area was proportional to the distribution of forest cover in the study area. In Huron, productive forest cover was about 51900 ha and in Perth about 19500 ha (See Table 2; Spectranalysis Inc. 1999). The mean area of woodlot harvest from entire NOI data set $(\mathrm{n}=1108)$ was $7.0 \mathrm{ha}$, with lowland woodlots averaging $7.6 \mathrm{ha}$ as compared to 6.5 ha for the upland woodlots. The median harvest area was 4.9 ha. The mean harvest area in the lowland and upland (7.0 and 6.3 ha) derived from the NOIs was consistent with the values from the contractor survey/interview dataset (Table 3, $\mathrm{n}=436$ ).

\section{Area sustainability calculation}

Based on the summaries of NOIs from 1997 to 1999, we calculated a mean annual harvest area equalling $4.7 \%$ and $3.7 \%$ of the privately owned deciduous forest in Huron and Perth Counties, respectively (Table 2). For the entire privately owned deciduous forest landbase across the two counties (53 $000 \mathrm{ha}$ ) approximately 7047 ha were harvested over the three-year period or $13.3 \%$, or a $4.4 \%$ annual harvest. Based on this rate, it would take nearly 23 years to conduct partial harvests in all the private woodlots within the study area. A 23 year-cutting cycle would be reasonable in this landscape if residual basal area targets, per stand, met or fell slightly below the provincial standards. At the ideal residual basal area of 20 $\mathrm{m}^{2} /$ ha a stand will grow to a harvestable basal area level (26 to $30 \mathrm{~m}^{2} / \mathrm{ha}$ ) in eight to 20 years (OMNR 2000).

\section{Volume summary}

Twenty contractors supplied harvest volume data on 436 NOIs (39\% of all NOIs). Five contractors who harvested greater than 200 ha contributed $80 \%$ of the data. The reported area harvested was 2872 ha (37\% of total harvest area of the study) for a total volume harvest of 15.14 million $\mathrm{fbm}$ in this subset of the study area (Table 3 ).

The mean harvest volume was $34725 \mathrm{fbm}$ per NOI woodlot or $5269 \mathrm{fbm} / \mathrm{ha}$. There was a significant difference between lowland and upland forest harvest volume per NOI and volume per area (Table 3). Mean lowland harvest was $43036 \mathrm{fbm}$ on 168 lowland sites compared to $29515 \mathrm{fbm}$ on 268 upland sites. Mean harvest volume in the lowland forest was signifi-

Table 3. Summary of harvest area and volume data from contractors surveyed. Values in rows followed by * are significantly different at $P<.01$

\begin{tabular}{|c|c|c|c|c|c|}
\hline Contractor variable & Lowland hardwood & $\%$ & Upland hardwood & $\%$ & Total \\
\hline NOI & 168 & 39 & 268 & 61 & 436 \\
\hline Total harvest area (ha) & 1177 & 41 & 1695 & 59 & 2872 \\
\hline Total volume harvested (Mfbm) & 7230 & 48 & 7910 & 52 & 15140 \\
\hline Mean volume (fbm) / NOI & $43036^{\star *}$ & - & $29515^{\star *}$ & - & 34725 \\
\hline Mean harvest area (ha) & 7.0 & - & 6.3 & - & 6.6 \\
\hline Mean volume/area (fbm/ha) & $6148^{* *}$ & - & $4666^{* *}$ & - & 5269 \\
\hline
\end{tabular}




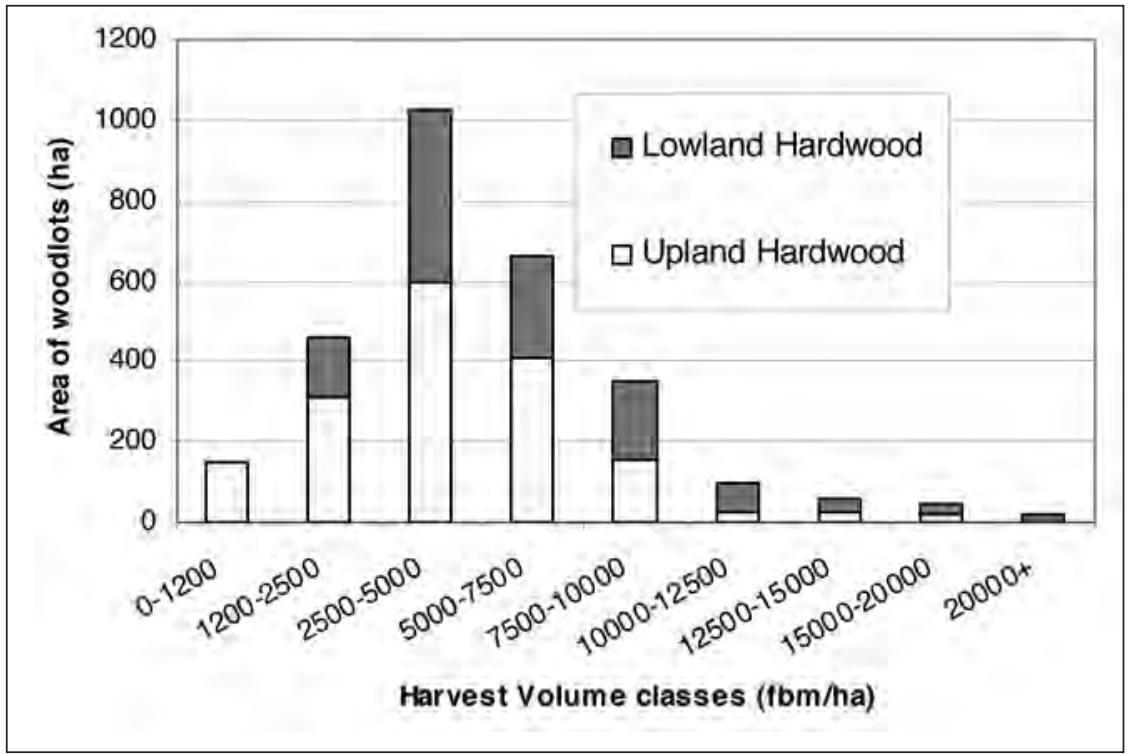

Fig. 2. Area of woodlots per harvest-volume class by forest type. ( $n=436 \mathrm{NOls}$ )

area harvested as upland forest area. Of the 17 woodlots with a harvest of more than $15000 \mathrm{fbm} / \mathrm{ha}, 10$ including the top three were lowland hardwood harvests. These mature even-aged stands had not been harvested in many decades. They comprised mainly trees above the by-law diameter limit resulting in a clearcut-like diameter-limit harvest.

\section{Estimating sustainability of wood volume}

As Table 4 indicates there is a range of potential volume growth from forests in southern Ontario and the northeastern United States. Miller (1993) suggested that volume growth rates are in the range of 500 to $1000 \mathrm{fbm} / \mathrm{ha} /$ year with the higher numbers coming from silviculturally managed stands. Miller (1993) also pointed out that sustainable harvests under these partial harvesting systems should not remove more than the

cantly greater $(6148 \mathrm{fbm} / \mathrm{ha})$ in comparison to the upland forest (4666 fbm/ha). Total volume from upland forests was 7.91 million fbm compared with 7.23 million fbm from the lowland forests.

There was some variation in timber volume reported by contractors. Contractors reported either on mill volumes (veneer removed) or on roadside volumes. Some contractors have the ability to harvest and utilize more low-quality trees because of their markets or ability to process low-quality logs. Fig. 2 shows the area of woodlots per harvest-volume class. Harvest volumes ranged from 5000 to $10000 \mathrm{fbm} / \mathrm{ha}$ in $35 \%$ of the woodlot area. At harvest rates greater than 15000 $\mathrm{fbm} / \mathrm{ha}$, there was more than twice as much lowland forest amount that will typically grow over the cutting cycle, i.e., harvest volume $(\mathrm{fbm} / \mathrm{ha})=$ cutting cycle length $($ years $) \times$ annual growth rate (fbm/ha/year). If we assume a 10 -year cutting cycle, then sustainable harvest volumes would range from 5000 to $10000 \mathrm{fbm} /$ ha depending on the site. This study found that $8 \%$ of the woodlot area ( $14 \%$ of the woodlots) had more than $10000 \mathrm{fbm} /$ ha removed, some of which removed twice this amount, leaving no commercial volume for 40 years or more. However, $13 \%$ of the lowland forest compared to $4 \%$ of the upland forest had this harvest rate. Another $35 \%$ of woodlot area is in the 5000 to $10000 \mathrm{fbm} / \mathrm{ha}$ range, which takes approximately seven to 14 years to grow. These may have been managed sustainably provided harvesting was

Table 4. Review of growth estimates from Ontario and similar United States forest and climate conditions.

\begin{tabular}{|c|c|c|c|c|c|}
\hline Location & Stand type & Regime & $\begin{array}{c}\text { Volume } \\
\text { range } \\
\mathrm{m}^{3} / \mathrm{ha} / \text { year }\end{array}$ & $\begin{array}{l}\text { Volume } \\
\text { range } \\
\text { fbm/ha/year }\end{array}$ & Source \\
\hline Huron/Perth & Upland and lowland forest & Typical management ${ }^{\mathrm{a}}$ & 1.7 & $400^{\mathrm{b}}$ & OMNR 1981 \\
\hline Huron/Perth & $\begin{array}{l}\text { Upland hardwoods } \\
\text { silviculture }\end{array}$ & Potential under intensive & 3.8 & 860 & OMNR 1981 \\
\hline Huron/Perth & Lowland hardwoods & - & 3.5 & 800 & OMNR 1981 \\
\hline Ontario Site Region 6E & Upland tolerant forest & Unmanaged stands & $3-4$ & $675-900$ & OMNR 2000 \\
\hline Ontario Site Region 6E & Upland tolerant forest & Managed stands & $4-6$ & $900-1350$ & OMNR 2000 \\
\hline Ontario Site Region 6E & Lowland forest & Unmanaged stands & $5-6$ & $1150-1350$ & OMNR 2000 \\
\hline $\begin{array}{l}\text { Central Appalachian } \\
\text { hardwoods }\end{array}$ & Upland forest & $\begin{array}{l}\text { SI }^{\mathrm{c}} 18 \\
\text { SI } 60\end{array}$ & 2.18 & 500 & $\begin{array}{l}\text { Miller et al. (1998) } \\
\text { referred to Trimble (1968) }\end{array}$ \\
\hline $\begin{array}{l}\text { Central Appalachian } \\
\text { hardwoods }\end{array}$ & Upland forest & $\begin{array}{l}\text { SI } 21 \\
\text { SI } 70\end{array}$ & 3.26 & 750 & $\begin{array}{l}\text { Miller et al. (1998) } \\
\text { referred to Trimble (1968) }\end{array}$ \\
\hline $\begin{array}{l}\text { Central Appalachian } \\
\text { hardwoods }\end{array}$ & Upland forest & $\begin{array}{l}\text { SI } 24 \\
\text { SI } 80\end{array}$ & 4.35 & 1000 & $\begin{array}{l}\text { Miller et al. (1998) } \\
\text { referred to Trimble (1968) }\end{array}$ \\
\hline Lake States & Upland forest & - & $2.18^{\mathrm{d}}$ & 500 & Eyre and Zillgitt (1953) \\
\hline
\end{tabular}

aIt is not clear whether "Typical management" means diameter-limit harvest or proper silviculture practice.

bValues rounded

'SI is a measure of site productivity. It is a measure of tree height at a standard age (usually 50 years) and varies according to species.

${ }^{\mathrm{d}}$ stand volume ranged between 4000 and $7000 \mathrm{fbm} /$ acre $\left(43.5\right.$ and $\left.76.3 \mathrm{~m}^{3} / \mathrm{ha}\right)$. 


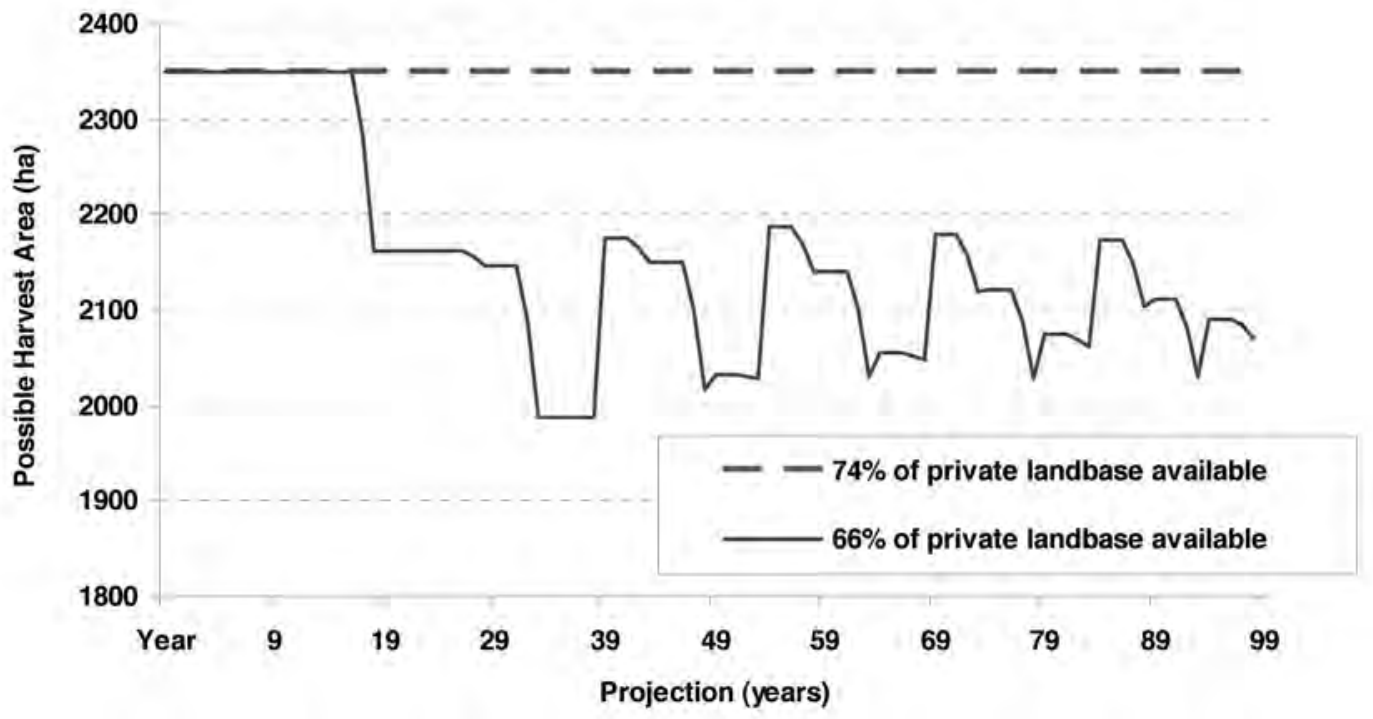

Fig. 3. Model of harvest area sustainability based on different rates of private land available for harvest.

under a silvicultural system and the past harvest left sufficient growing stock. Lastly, 57\% of woodlot area was below the $5000 \mathrm{fbm} /$ ha range and were not likely over-harvested; however, this does not ensure that a silviculture system was employed and that thinning focused on future productivity. At a minimum, $8 \%$ of the woodlot area was harvested at a rate that is not sustainable and other woodlots within the middle volume harvest class may also be experiencing over-harvesting based on this calculation.

\section{Model of harvest rate}

To clarify whether harvesting on the available private deciduous forest landbase in Huron and Perth can be sustained at the rates observed, we developed a simple model that includes data from both the area and volume components of the study. The model makes the following conservative assumptions:

1. Based on the current proportion of single-tree selection and stand improvement marking $8 \%$ of the area harvested will have a 10 -year cutting return time.

2. Based on the volume summaries which identified overharvesting, $8 \%$ of the harvest area will require at least a 40 year cutting return time.

3. The remaining $84 \%$ area has uncertain growth rates and should be given a conservative cutting return time of 15 years.

Using the annual harvest area calculated in our study (2349 ha/yr), the model indicated that at least $74 \%$ of the private deciduous forest landbase would be required to sustain this level of harvest for 100 hundred years (See Fig. 3). Our study did not confirm the level of interest in timber harvesting by the private woodlot owners. A comprehensive nationwide survey conducted by Environics (2000) found rural landowners were on average only 33\% (32\% non-farmer and $34 \%$ farmer) interested in timber harvesting. If fewer landowners in Huron and Perth were interested in harvesting and the woodland availability dropped to $33 \%$ of the private landbase, our observed rate of harvesting (2349 ha/yr) can only be sustained for seven years and many future years would have little or no harvesting at all over the 100-year projection. Informal discussions with landowners and county officials (Marvin Smith ${ }^{5}$, personal communication, 2002) suggest there is a long tradition of timber harvesting in these agricultural communities and it is expected to continue into the near future. At the very least we expect two-thirds of these landowners to continue with harvesting. Under this scenario, with $66 \%$ of the private landbase, the 1997 to 1999 rate of harvesting (2349 ha/yr) represents an over-cutting. This level of harvesting could only be sustained for 18 years, while the remaining 82 years of the 100 -year modeling horizon reflects a declining, inconsistent, lower level of harvesting (see Fig. 3). At $66 \%$ of the private landbase the area harvested annually would need to drop to $2107 \mathrm{ha} / \mathrm{yr}$ to be sustainable, representing a $10 \%$ decline in the amount of area and subsequent volume annually available to the forest industry.

\section{Woodland ecosystem impacts}

\section{Harvest area by forest type}

Fig. 4 shows the distribution of harvest area by forest type. Upland hardwood forest accounted for 56\% (4354 ha) of the harvest area, lowland hardwood forest 35\% (2693 ha) and plantation harvest $3 \%$ of the area. Just over $6 \%$ of the forest area could not be accurately classified without field surveys. Market demand for lumber increased harvesting of lowland forests in 1998 and 1999. Fortunately, lower than average precipitation allowed for greater access. Some areas were dry enough to allow skidding (without severe site damage) for the first time in some farmers' lifetime (A. Craig ${ }^{6}$, personal communication, 2001). Fig. 5 shows the year-to-year change in harvest levels.

${ }^{5}$ Forest Conservation By-law Officer, County of Perth

${ }^{6}$ Owner, Craig Sawmill, Auburn Ontario; now retired 


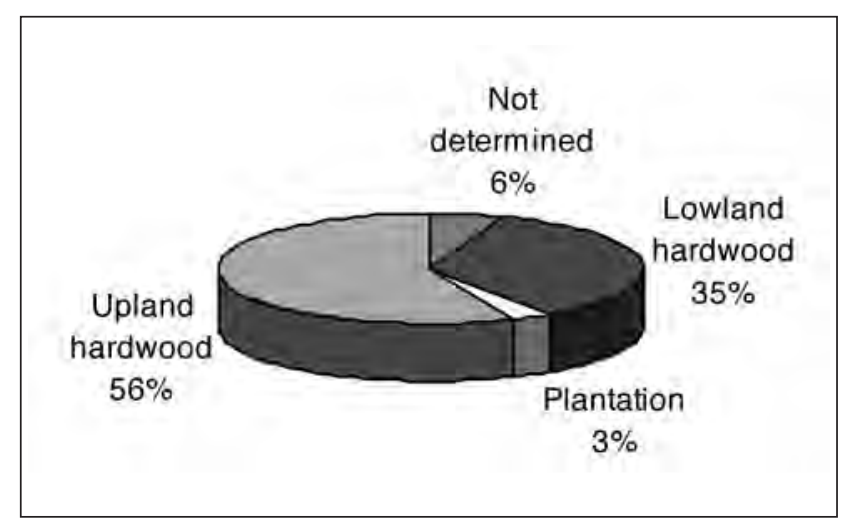

Fig. 4. Distribution of harvest area by forest type. (Area $=7714$ ha; $n=1108$ NOls);

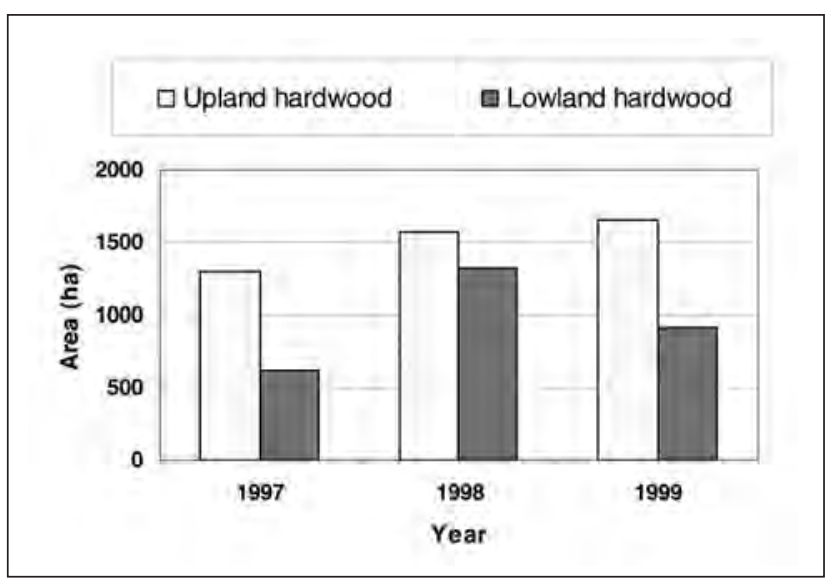

Fig. 5. Distribution of harvest area by forest type. (Total = 91\%; plantation and not classified $=9 \%$; area $=7047$ ha

\section{Harvest volume by tree species}

Data on the species harvested came from 358 contractor submissions. Sugar maple and soft maple were the most commonly harvested species, providing $33 \%$ and $31 \%$ of harvest volume respectively. Ash volume (all species) was $21 \%$. The following species or species groups also contributed to the volume: beech $(3.5 \%)$, black cherry $(2.4 \%)$, oak $(0.6 \%)$ and pine $(0.1 \%)$. Hickory, basswood and elm composed most of the remaining $7.6 \%$ of the harvested volume. A minor portion of the total volume consisted of poplar/aspen, yellow birch, hemlock, cedar and black walnut. Harvested tree species composition was in proportion to tree composition for the study area with the exception of a disproportionately high amount of soft maple harvested due to better accessibility in 1998 and 1999. (Bowles et al. 2001).

\section{Forest management practices}

Four independent forest consultants supplied 301 tree marking records. They tree-marked (identified trees for harvest with paint) an area of 2067 ha and a volume of 8.0 million $\mathrm{fbm}$. Table 5 summarizes the area marked for the study area. In 1998, a total of 869 ha was marked (highest amount of area marked) while the annual mean over the three-year period was 689 ha. The tree marking data were obtained independently of NOI data collection and the contractor data survey. For example, many woodlots marked in 1999 did not have a

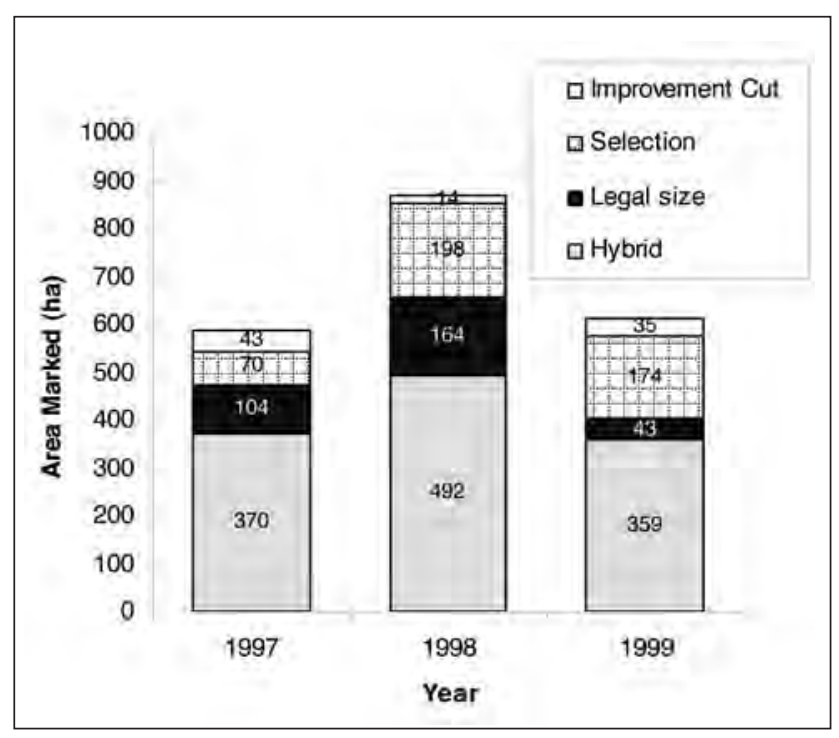

Fig. 6. Annual area marked by independent consultants by marking type. ( $n=301$ tree marking records; area = 2067 ha)

Table 5. Number, total area and mean area of woodlots marked by independent consultants in the study area from 1997 to 1999.

\begin{tabular}{lrrrr}
\hline & \multicolumn{4}{c}{ Year Marked } \\
\cline { 2 - 5 } Forest type & $\mathbf{1 9 9 7}$ & $\mathbf{1 9 9 8}$ & $\mathbf{1 9 9 9}$ & Total \\
\hline Upland \# of woodlots marked & 65 & 71 & 57 & 193 \\
$\quad$ Area marked (ha) & 405 & 439 & 373 & 1218 \\
Mean woodlot area (ha) & - & - & - & 6.3 \\
& & & & \\
Lowland \# of woodlots marked & 26 & 46 & 36 & 108 \\
$\quad$ Area marked (ha) & 181 & 429 & 238 & 848 \\
$\quad$ Mean woodlot area (ha) & - & - & - & 7.9 \\
Total \# of woodlots marked & 91 & 117 & 93 & 301 \\
Total area marked (ha) & 587 & 869 & 611 & 2067 \\
Total mean woodlot area (ha) & - & - & - & 6.9 \\
\hline
\end{tabular}

NOI filed and were not logged until 2000 or later and were not included (area marked in 1996 and logged in 1997 were included). Over the three-year period, consultants marked approximately $29 \%$ (2067 ha of $7047 \mathrm{ha}$ ) of the privately owned deciduous area harvested. The area marked was $32 \%$, $32 \%$ and $25 \%$ of the deciduous harvest in 1997, 1998 and 1999 , respectively.

The consultants conducted tree-marking under four different regimes: 1) single-tree selection 2) improvement cutting, 3) legal size as defined in the by-law (diameter limit) and 4) hybrid (Fig. 6). Only 26\% (534 of 2067 ha) of all marking by the independent consultants was for single-tree selection silviculture or improvement cutting - a mere $8 \%$ of the entire deciduous harvest. However, the percent of area marked by selection or improvement cutting increased every year from $19 \%$, to $24 \%$, to $34 \%$ of the total area marked. The most common type of marking used by consultants was hybrid (59\%), while $15 \%$ was marked to legal size (diameter-limit). All other harvesting and marking (e.g., $74 \%$ by the loggers) was done according to legal-size regulations of the by-law. 


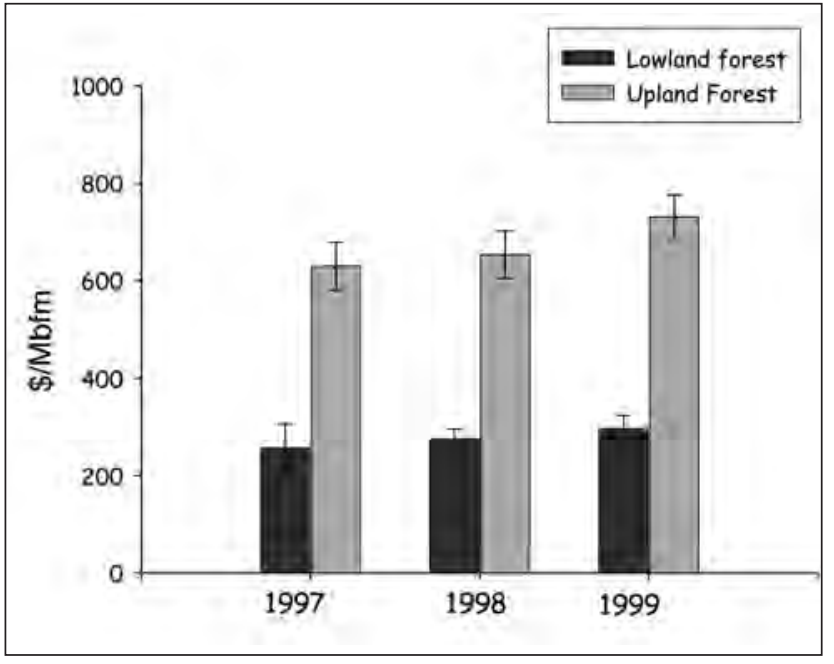

Fig. 7. Annual value of timber paid to landowners on a volume basis ( $\pm \mathrm{SE})$. ( $n=178 \mathrm{NOIs}$ )

Economic value of forest harvesting to landowners Eleven contractors supplied price and volume information on 158 operations ( $14 \%$ of NOIs). The range was two to 31 submissions per contractor. As well, prices were obtained directly from landowners on six operations but no volumes were available. Prices and volumes on a further 20 operations were obtained from consultants. This resulted in 184 NOIs (16.6 $\%)$ with price information that we have used to estimate timber values. On a volume basis, the average price for timber paid to landowners was $\$ 680 / \mathrm{Mfbm}$ standing on the upland hardwood woodlots and this was significantly higher than the price of $\$ 281 / \mathrm{Mfbm}$ standing paid on the lowland hardwood forest. On an area basis, the mean price paid on upland hardwood woodlots was $\$ 3680 /$ ha, which again was significantly higher than the lowland hardwood forest average of $\$ 1956 /$ ha. Fig. 7 and Fig. 8 show the mean value of woodlot harvest on a volume and on an area basis, respectively.

Fig. 9 compares the range of prices paid for the timber in the upland and lowland forests. Prices for lowland hardwood had a mean of $\$ 281 / \mathrm{Mfbm}$ standing. Prices for the upland hardwood were more variable and multi-modal due to differences in value among species.

Fig. 10 shows the ratio of price paid to volume harvested in each operation. Upland and lowland forests showed distinct ranges with $r$ values of 0.89 and 0.81 , respectively, indicating the value of harvest from each forest type. Data points falling between the lines (especially for upland forest harvests) are the result of mixed stands of upland and lowland forest in a sale and differences in species composition and value.

Landowners in Huron and Perth Counties received a little under \$6 million for their timber harvested in 1997 and slightly over $\$ 8.8$ million in 1999 (Table 6). Total timber sales amounted to $\$ 22.7$ million. The average value to the landowner during this period was about $\$ 24000$ for their standing timber. These estimates did not account for fuelwood or harvest from conifer plantations.

\section{Discussion}

\section{Forest harvest and sustainability}

There is no specific information to describe forest growth in the study area and work that has been done in Ontario and

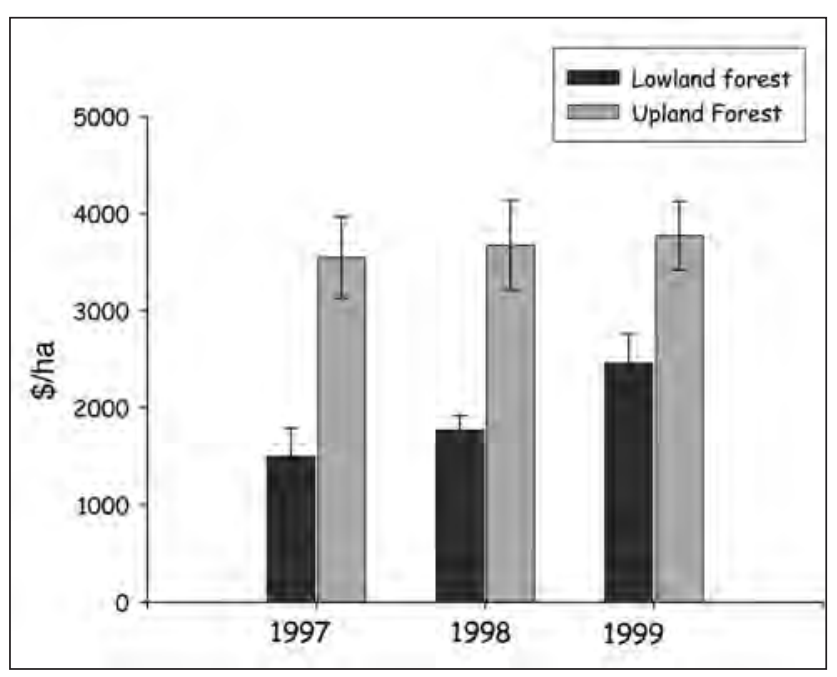

Fig. 8. Annual value of timber paid to landowners on an area basis ( $\pm \mathrm{SE}$ ). ( $n=184 \mathrm{NOls}$ )

elsewhere was usually based on harvesting under a regulated approach, such as with the selection system (OMNR 2000). It has been documented that although in some cases (Smith and Miller 1987) comparable volumes can be grown under diameter-limits, they are usually lower, unreliable, inconsistent and of a reduced quality (Kenefic and Nyland 2005). It is therefore difficult to define a level of sustainable harvest under primarily a diameter-limit harvesting program. For upland hardwoods managed under the selection system, most research suggests a 15-year cutting cycle with a range from 10 to 25 years. A ten-year cycle can be used where there is good accessibility, high timber value, productive sites and adequate markets (Leak et al. 1987, Miller 1993); these conditions apply in most of southwestern Ontario.

In this landscape, a $4.4 \%$ annual harvest rate by area would be sustainable under the selection system. However, the most common harvest methods used in this study, diameter-limits and hybrid (92\% of area), focus on good-quality sawlogs, remove higher volumes, degrade forest genetic quality, health, value and stand structures (Kenefic and Nyland 2005). This puts significant pressure on sustainable wood supply over the long term. Under these conditions, the return rates may need to be extended to as much as 40 years, making this unsustainable at the shorter cutting cycles.

The actual area of the landbase available for harvest is also in question. Three main factors can remove or delay forest area available for harvest:

1. Area not suited to commercial harvest - Historical inventories ${ }^{7}$ and casual observation (Schwan) indicate that as much as $25 \%$ of the current area of forest is either too young or comprised of intolerant species and would not be available for a minimum of 40 years and likely much longer.

\footnotetext{
${ }^{7} \mathrm{~A}$ broad approximation of the inventory is provided by OMNR (2002). The report summarizes the age class information from the 1978 Forest Resource Inventory by Site Regions and major species. For tolerant hardwoods (e.g., maple, ash) age class 0 to 20 years occupied $21 \%$ and $27 \%$ of the hardwood forest area in Site Region $7 \mathrm{E}$ and $6 \mathrm{E}$, respectively.
} 


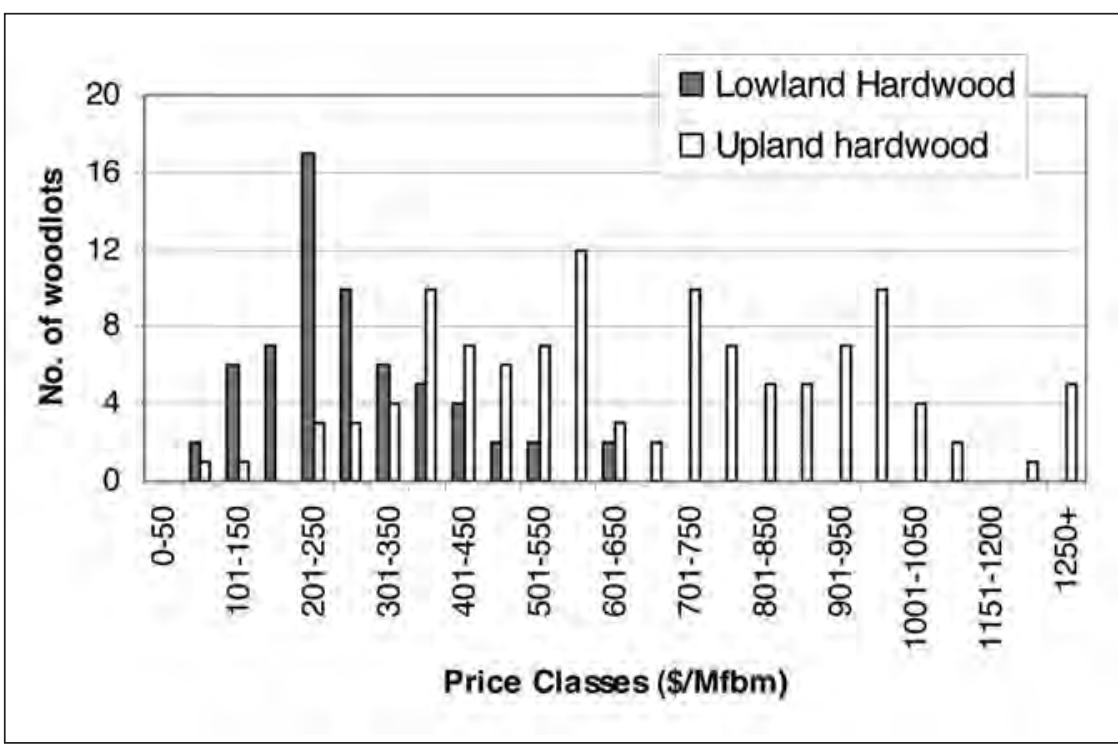

Fig. 9. Comparison of price paid by forest type. ( $n=178$ NOls $)$

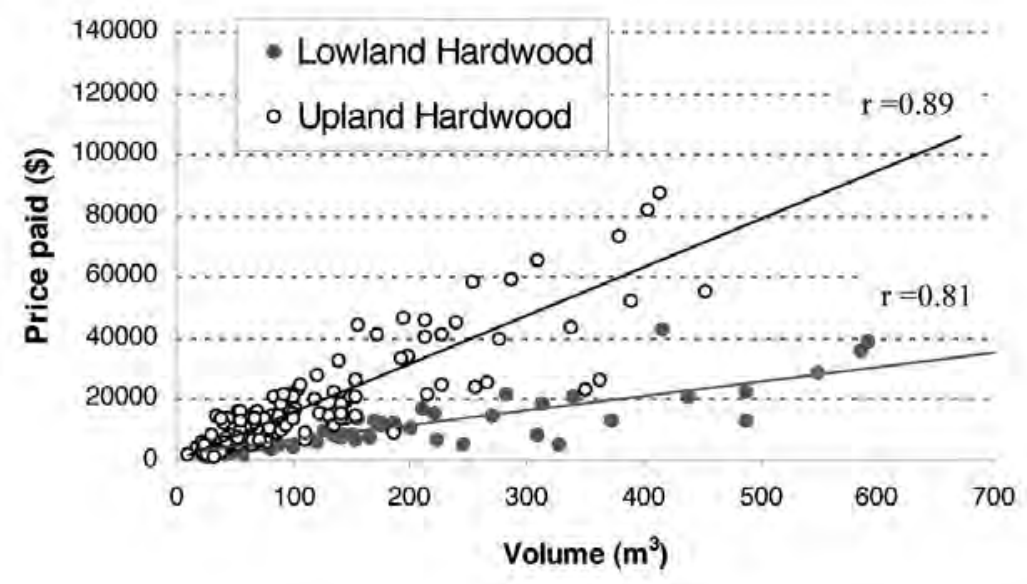

Fig. 10. Relationship of price vs. volume by forest type. ( $n=184$ NOls)

2. Area over-harvested - This study indicates that $8 \%$ of the area has been over-cut and may require at least 40 years growth before another commercial harvest will be possible based on our calculations.

3. Landowner uninterested in harvesting - There is survey evidence that rural landownership is moving towards people with less interest in forest harvesting (Factor Research Group 1995, Petersen 1996, Environics Research Group 2000). Surveys were telephone and/or mail surveys to rural landowners throughout southern Ontario, the Rideau Valley watershed in eastern Ontario and in the Deciduous Forest Region, respectively. These surveys indicated that as few as one-third of landowners are interested in harvesting. Using one-third of the private landbase (17 $490 \mathrm{ha}$ ) in Huron and Perth as the available harvest scenario, our model found the maximum sustainable harvest rate to be $1053 \mathrm{ha} / \mathrm{yr}$. This is $55 \%$ less than the observed rate for 1997 to 1999 . Our investigations indicate that there is a long tradition of woodlot harvesting in this area and it has continued through the 1990s and likely up until today (Marvin Smith, personal communication, 2002). Based on the model, this traditional interest needs to include a minimum of $74 \%$ of the private landbase or the studied level of harvest cannot be sustained.

These three factors may reduce the forest area available for harvest. Although there is likely some overlap, it would be reasonable to assume that the harvest is actually concentrated on an area that may be up to $35 \%$ smaller than our calculations indicate. The actual harvest rate on the available forest may be much higher than $4.4 \%$ of that area per year. This places some doubt on the sustainable wood supply, given that most of the area is not managed under a silvicultural system.

\section{Woodland ecosystem impacts}

In the upland shade-tolerant hardwood forests of the study area, the single-tree selection system is the recommended silvicultural practice that is sustainable, allows for periodic economic returns, emulates natural tree-fall-gap disturbance, and provides the best opportunity to maintain wildlife and other sensitive features (OMNR 2000). In the lowland hardwood forest, partial harvesting is also recommended and can range from single-tree selection and group selection, to shelterwood systems (OMNR 2000). In both forest types, good forestry practice and forest health is achieved through a system of data collection, silvicultural prescription preparation, tree marking and careful logging (OMNR 2000). In this study, we observed that only $8 \%$ of landowners obtained tree marking services from consultants practising the recommended silviculture. Most landowners instead chose short-term economic gains utilizing a diameter-limit or hybrid approach, which were legal under the tree by-laws in place at the time. Diameter-limit cutting is not considered to be good forestry practice and is not recognized as an appropriate silviculture system (OMNR 2000, Kenefic and Nyland 2005). Nevertheless, it is the main prescription used by loggers and too often used by consultants. Some contractors have taken the Provincial tree marker certification training and are using those principles to mark woodlots for harvest. Unfortunately, it is not known how often this occurs.

Historically in Ontario, the Ministry of Natural Resources (OMNR) provided free private land forestry extension services that included site visits and a program to assess woodlots, conduct tree marking under silvicultural prescriptions, calculate volumes and assistance with wood product marketing and timber sales (Elliott 1998). These programs operated for 
Table 6. Estimated value to landowners from hardwood timber harvest from 1997 to 1999 . Value is the product of area and price in each matrix point, respectively. Price for unclassified area $[\$ /$ ha] was determined relative to the area harvested on upland/lowland. Plantation harvest area not included. This accounts for the difference in area from Table 1.

\begin{tabular}{lrrrr}
\hline & $\mathbf{1 9 9 7}$ & $\mathbf{1 9 9 8}$ & $\mathbf{1 9 9 9}$ & Total \\
\hline $\begin{array}{lrrr}\text { Area (ha) } \\
\text { Unclassified }\end{array}$ & 202 & 102 & 123 & 426 \\
Lowland & 591 & 1209 & 893 & 2693 \\
Upland & 1257 & 1501 & 1596 & 4354 \\
Total & 2051 & 2812 & 2611 & 7473 \\
& & & & \\
Price (\$/ha) & & & & \\
Unclassified & 2751 & 2968 & 3328 & - \\
Lowland & 1499 & 1785 & 2459 & - \\
Upland & 3551 & 3726 & 3884 & - \\
& & & & \\
Value (\$ 000s) & & & & \\
Unclassified & 555.9 & 301.7 & 408.4 & $\mathbf{1 2 6 6 . 0}$ \\
Lowland & 886.2 & 2157.4 & 2196.2 & $\mathbf{5 2 3 9 . 8}$ \\
Upland & 4463.6 & 5593.9 & 6197.6 & $\mathbf{1 6 2 5 5 . 0}$ \\
Total & $\mathbf{5 9 0 5 . 7}$ & $\mathbf{8 0 5 2 . 0}$ & $\mathbf{8 ~ 8 0 2 . 2}$ & $\mathbf{2 2} \mathbf{7 6 0 . 8}$ \\
\hline
\end{tabular}

about 25 years but were discontinued in 1994. Slowly, private forestry consulting on a fee-for-service basis and landowner associations have partially filled the needs for forest management advice, while the OMNR has focused on enhanced information products, education and training programs, tax incentives and community-based stewardship programs (OMNR 1997, 2001). Within our study area between 1989 and 1991 approximately 468 ha were marked annually under the OMNR's Private Land Forestry Program ${ }^{8}$. By comparison, in our study only 178 ha were marked annually for selectionsystem harvest and improvement cut. This represents a $62 \%$ reduction in the level of tree marking. Future data collection will clarify if there is an increase in the uptake of private tree marking services. Clearly, incentives, better marketing, or changes in tree cutting by-laws could improve the compliance with good forestry practice.

Lowlands or wetlands are often sensitive ecosystems that support numerous important functions, habitats and species at risk. In southern Ontario, in addition to the problems noted for diameter limits, over-harvesting, poor harvest timing and poor choices of equipment have degraded lowland forests, increasing tree decline and mortality and stalling regeneration due to rising water levels and changes in drainage (OMNR 2000). Our study identified an increase in the rate of harvesting of lowlands during the three-year time period. This was most likely due to improved access due to

${ }_{8}^{8}$ In that era Wingham District included Huron and Perth Counties and the four southern townships of Bruce County, as well as Minto Township in Wellington County. Tree marking summaries by township from 1971 to 1979 indicate that $75 \%$ of the marking in Wingham District was done in Huron and Perth. The estimated area marked in Huron and Perth in 1989 to 1991 was the District total of 624 ha annually times $0.75=468$ ha. drier conditions and combined with improved markets for the lowland hardwood species. In addition, lowland forests were also the area with the greatest proportion of over-harvesting and where all of the severely over-cut woodlots were found. This represents a heavy disturbance and significant changes to wetland ecosystems, and raises concerns regarding the resiliency of species and ecological functions that these areas support. Comparatively, upland forests are harvested at shorter, more regular intervals because they support more valuable tree species, are more accessible, obtain natural regeneration consistently and can be harvested more economically. These harvest areas and volumes are likely comparable to other areas in Ontario with similar landforms, climatic conditions and regulation methods.

Mapping (not included in this report) indicated some clear trends in forest size and harvest location. Forest harvest is shown to be concentrated in the areas with the highest percent forest cover. Landform and post-settlement agricultural practices influenced woodlot location and size. Typically throughout southern Ontario, forests are distributed at the back of the property, a pattern clearly visible in Fig. 1. Woodlots on the rich till plain tend to be smaller and, along a few concessions, are often non-existent due to intense agricultural practices. Our study found the harvesting to be spread across many relatively small woodlots with an average size of seven hectares. To capitalize on economies of scale, logging contactors tend to negotiate harvest agreements with a number of neighbouring woodlot owners, which concentrates harvest area in a given year. Often, many of the adjoining woodlots along the rear of properties between concession roads are harvested in one season. This practice concentrates singleyear disturbances in certain areas and does not consider past management. If most woodlots over large sections of the landscape are disturbed at the same time (one to five years) with the same type of prescription (i.e., diameter-limit), the forest diversity and structure may be simplified (Hunter 1990).

\section{Economic value of forest harvesting to landowners from 1997 to 1999}

Woodlot owners in our Huron and Perth County study had an average income of approximately $\$ 24000$ per harvest from a 6.6-ha upland woodlot. Based on an expected 15-year cutting cycle this amounts to $\$ 1600$ per year. Most of these woodlot owners rely on natural regeneration, have low land tax rates and spend little if anything on the management and maintenance of their woodlots. As such, revenue from harvesting is mostly profit. Findings from simulation studies for uneven-aged sugar maple stands suggest less long-term sawlog yield and stumpage value from stands operated by diameter-limit removals compared to selection system cutting (Nyland 2005). The only advantage to diameter-limit cutting is the high volume and value realized in the first cycle. Selection system harvests sustain a higher level of long-term production and greater consistency in recovered volume and value through time. Keeping forested lands on farms is an economic way to manage lands when compared to other agronomic land uses such as row crops or grazing. If proper silviculture was employed, cutting cycles could be reduced and quality improved, which would further increase the profitability of managing these forest resources. 
The value for both sugar and soft maple improved over the three-year study period. We saw an increase in prices paid for timber and an increase in landowners choosing to harvest, and in some cases over-harvest, or cut more than recommended under good silviculture, in order to increase shortterm revenue. This heedless decision-making is an all too common trend in private woodland harvesting in the region and is challenging the sustainability of eastern hardwood forests (Nyland 1992). As well, experienced timber buyers knew the value and volume they were buying and were consistent in the price they paid for those volumes.

\section{Conclusions and Recommendations}

The current non-silvicultural approach to forest harvesting typical in Huron and Perth Counties produces a reasonable once-per-generation income. This is often at the expense of a more regular income from an intact productive woodland ecosystem. By continuing to harvest at the rates found between 1997 and 1999 it is likely that the private woodlands of Huron and Perth Counties and others with these rates will continue to be degraded. Since growth rates are reduced in these understocked, lower quality stands future harvest rates would need to be reduced when merchantable timber becomes less available and this could occur in as few as 18 years (2017). Proper silvicultural practices would maintain healthier forests that would produce sustainable volumes of better value at shorter intervals, more consistently over time. With landowner interests moving away from harvesting, it is imperative that the remaining harvestable woodlands are managed for growth and the production of high value goods, while maintaining the broad spectrum of ecological services. We hope these messages will encourage more landowners and managers to choose sustainable, silvicultural harvests for their woodlots.

This study has shown there are a number of gaps in our knowledge of forest utilization. These knowledge gaps apply to private land in most of southern Ontario. We propose the following recommendations:

1. Complete a digital forest inventory. The last inventory was not digital and was completed in 1978. This will allow for quick input into computer modeling programs that can be used to illustrate the regional implications of various silviculture methods and harvesting intensities. It would have provided this study with an accurate view of upland/lowland forest area as well as age class distribution to determine area of forest available for harvest over time.

2. Redo this survey in ten to fifteen years time. This will allow monitoring of improvements or declines (trends) in forest management of private lands, silvicultural practices or lack thereof, volumes recovered and returns on products. As a result in changes in the economy the forest industry has downsized. Less wood is being cut and there are fewer operators. There are a greater number of forest consultants working in the area. Some of the by-laws have changed to encourage good forestry practice. A new survey is underway covering the years 2006 to 2009 .

3. Establish new growth plots in the lowland hardwood forest. Presently there are only four OMNR plots of the soft maple-ash forest type in southwestern Ontario. For development of yield curves or growth/succession models a range of stocking and seral stages and a productivity gra- dient is needed. Growth and yield staff suggest that at least 30 plots, with three remeasurements, are required.

4. Conduct a study on lowland hardwood forest (soft maple, ash, elm) to provide suggested silvicultural practices and long-term sustainability. This is one of the least studied but most sensitive forest types in North America. Establishment of a series of growth plots in this forest type is a first step in understanding forest dynamics. Forest regeneration is poorly understood and is highly dependent on water levels in these wet sites. New information will provide better management advice and direction for ecosystem management that is both sustainable and economic.

5. Complete a science-based modeling comparison of good forestry practice vs. diameter-limit harvest. This has not been done specifically for southern Ontario. This comparison should have real value as an extension tool and as an important foundation for educational initiatives. OMNR Southern Science staff plan to conduct this study starting in 2010.

6. Develop and carry out a survey of behaviour and attitudes of rural landowners for 2010. The last one was completed in 2000 . That survey provided a understanding of the forest attitudes of the day. A second and third survey would show trends. Most important is the changing demographic of the aging baby boomers.

\section{Acknowledgments}

We would like to gratefully acknowledge the assistance of the numerous contractors and consultants who contributed the data for this project.

The following municipalities and Conservation Authorities supplied Notice of Intent and forest data; Perth County, Huron County, Maitland Valley Conservation Authority, Ausable Bayfield Conservation Authority and Upper Thames Region Conservation Authority.

We particularly wish to thank Mark Vanderwel, Summer Technical Assistant, for his assistance in data collection and technical support, and for conducting the database management. The Maitland Watershed Partnerships provided monetary support. Phil Beard, Rick Steele, Noah Gaetz and Darren Kenny of the Maitland Valley Conservation Authority provided support and guidance in this project. Jane Bowles provided excellent editorial and philosophical support. We thank Dawn Burke for statistical advice and two anonymous reviewers for their constructive advice.

\section{References}

Bowles, J.M., N. Gaetz, T.D. Schwan and R. Steele. 2001. Assessing forest health in the Maitland Watershed. Maitland Watershed Partnerships. Poster.

Chapman, L.J. and D.F. Putnam. 1984. The Physiography of Southern Ontario. Ontario Geological Survey, Special Volume 2. 270 p.

Elliott, K.A. 1998. The forests of southern Ontario. The Forestry Chronicle 74(6): 850-854.

Environics Research Group. 2000. Survey of farmers, ranchers and rural landowners - Attitudes and behaviours regarding land stewardship. 37 p. + appendices. Available from Wildlife Habitat Canada at http://www.whc.org/files/environicslandownersfinal.pdf

Eyre, F.H. and W.M. Zillgitt. 1953. Partial cutting in northern hardwoods of the Lake States - Twenty-year experimental results. Technical Bulletin No. 1076. U.S. Department of Agriculture, Forest Service, North Central Forest Experimental Station. 124 p. 
Factor Research Group Inc. 1995. Rural Landowner Survey. Final Report. Unpublished. Landowner Resource Centre, Manotick, ON. 30 p. + Appendices

Hills, G.A. 1959. A ready reference to the description of land of Ontario and its productivity. Ontario Department of Lands and Forests, Maple, ON. 142 p.

Hunter, M.J. 1990. Wildlife, forests, and forestry: principles for managing forests for biological diversity. Prentice-Hall, Inc., Simon and Schuster Company, Englewoods Cliffs, NJ. 370 p.

Kenefic, L.S. and R.D. Nyland. 2005. Diameter-limit cutting and silviculture in northeastern forests: a primer for landowners, practitioners, and policymakers. U.S. Department of Agriculture, Forest Service, Northeastern Area State and Private Forestry NA-TP-02-05, Newtown Square, PA. 18 p.

Leak, W.B., D.S. Solomon and P.S. DeBald. 1987. Silvicultural guide for northern hardwood types in the Northeast (revised). Res. Pap. NE-603. U.S. Department of Agriculture, Forest Service, Northeastern Forest Experimental Station Broomall, PA. 36 p.

Miller, G.W. 1993. Financial aspects of partial cutting in central Appalachian hardwoods. Res. Pap. NE-673. U.S. Department of Agriculture, Forest Service, Northeastern Forest Experimental Station, Radnor, PA. 9 p.

Miller, G.W.; K.A. Elliott and E.P. Boysen. 1998. The Central Appalachian hardwoods experience provides silvicultural tools for Ontario. OMNR. South Central Sciences Technical Report No. 005. $23 \mathrm{p}$.

Nyland, R.D. 1992. Exploitation and greed in eastern hardwood forests: Will foresters get another chance? Journal of Forestry. 90(1): 33-37.

Nyland, R.D. 2005. Diameter-limit cutting and silviculture: A comparison of long-term yields and values for uneven-aged sugar maple stands. Northern Journal of Applied Forestry 22(2): 111-116.

[OMNR] Ontario Ministry of Natural Resources. 1981. Background Information Wingham District Land Use Strategy. Internal Report.

1997. Ontario Ministry of Natural Resources Annual Report 1995-96. Ont. Min. Nat. Resour. Queen's Printer for Ontario. Toronto. $64 \mathrm{p}$.

. 2000. A Silvicultural Guide to Managing Southern Ontario Forests, Version 1.1. Ont. Min. Nat. Resour. Queen's Printer for Ontario. Toronto. $648 \mathrm{p}$.

2001. Annual Report on Forest Management 1999/2000.

Ont. Min. Nat. Resour. Queen's Printer for Ontario. Toronto. 118 p.

2002. Forest Resources of Ontario 2001. Appendix 1 of the

State of the Forest Report 2001. Ont. Min. Nat. Resour. Queen's Printer for Ontario. Toronto. 137p.

Petersen, J. 1996. Landowner Survey Report. Unpublished. Carolinian Canada. 12 p. +appendices.

Rowe, J.S. 1972. Forest Regions of Canada. Canadian Forestry Service Pub. \#1300. Department of Environment, Ottawa. 172 p.

Smith, D.M. 1986. The Practice of Silviculture. $8^{\text {th }}$ Ed. John Wiley \& Sons, Inc., New York. 527 p.

Smith, H.C. and G.W. Miller. 1987. Managing Appalachian hardwood stands using four regeneration practices- 34 year results. Northern Journal of Applied Forestry 4: 180-185.

Spectranalysis Inc. 1999. Ontario Land Cover Data Base Revised User's Manual. Report to the Ontario Ministry of Natural Resources. Unpublished.

Trimble, G.R. 1968. Growth of Appalachian hardwoods as affected by site and residual stand density. Res. Pap. NE-98. U.S. Department of Agriculture, Forest Service, Northeastern Forest Experimental Station, Upper Darby, PA. 13 p.

Voros, S. 2008. Unpublished data analysis. Ontario Ministry of Natural Resources.

\section{Note on English Metric usage}

The units of measurement used by forest industry and most forest landowners are acres, thousand foot board measure (Mfbm) and cords. Units used in this study were collected using the English system.

\section{Conversions Factors}

hectares $\times 2.47=$ acres

acres $\times 0.405=$ hectares

$\mathrm{Mfbm}=1000$ foot board measure $(\mathrm{fbm})$

\section{Note about log rule measurements}

In Ontario, standing timber is estimated by consultants using the Ontario log rule. Timber and logs are bought and sold by contractors using the Doyle log rule. In the U.S. the Doyle, Scribner and International $1 / 4$ " rules are used depending on location and intended purpose. The Doyle rule underestimates standing timber by $15 \%$ for 20 inch $(50 \mathrm{~cm})$ diameter breast height $(\mathrm{DBH})$ trees and up to $30 \%$ for 16 inch $(40 \mathrm{~cm})$ $\mathrm{DBH}$ trees. There is no industry standard for determining the volume or grade of sawlogs. The owner-contractor of each mill uses the method of their choice.

\section{Appendix I. Explanation of calculation of deciduous forest cover} on private land.

The Ontario Land Cover data, which were derived from digital, multispectral LANDSAT Thematic Mapper data, provided a breakdown of forest types that was used for this analysis (Spectranalysis Inc. 1999). Categories used to determine available forest area for harvest included 1) dense deciduous forest, 2) mixed forest mainly deciduous and 3) deciduous swamp. Categories not included were 4 and 5) sparse deciduous and coniferous forest, 6) mixed forest mainly coniferous, 7) dense coniferous forest, 8) coniferous swamp and 9) plantation. This provided adequate information to determine forest area.

For example, in Perth County the "total forest area" of all nine forest categories was 19501 ha. The area covered by the categories 1 to 3 was about 15500 ha. This lesser area was used as the "deciduous forest area". The estimated "public deciduous forested area" (500 ha) was subtracted from this and the result was the "privately owned deciduous forest area" (15 000 ha). The "deciduous forest harvest area" (1671 ha) was divided by 15000 ha to obtain percent of deciduous forest harvested, in this case $11.1 \%$. 